\title{
Perception of Climate Change and Livelihood of a Farming Community of Maruf Kebele, Central Oromia, Ethiopia
}

\author{
Olika Belachew, Muhammad Iqbal Zuberi \\ Department of Biology, Ambo University, Ambo, Ethiopia \\ Email: iqbal.zuberi@gmail.com
}

Received 9 January 2015; accepted 20 June 2015; published 23 June 2015

Copyright (C) 2015 by authors and Scientific Research Publishing Inc.

This work is licensed under the Creative Commons Attribution International License (CC BY). http://creativecommons.org/licenses/by/4.0/

\section{(c) $($ )}

\section{Abstract}

The farmers' perception of climate change and their response was documented in Maruf Kebele of Central Oromia, Ethiopia with questionnaire survey, focus group discussion and field observation. Over hundred randomly selected households were included; the community typically includes a large proportion of small holder farmers from poorly equipped, land scarce households with low education and economic status. The results indicated that farmers had a good understanding and perception of the impacts of climate change at the local level; many negative impacts of the climate irregularity had been identified by the community, like reduced crop yield, heating/drying up of environment and soil loss affecting natural plant regeneration from the forest soil seed bank, drying up of streams and springs, disappearance of trees and plants, rarity of wild animals and increasing pests/diseases. Farmers were observed to diversify their livelihood options as part of responding to irregularities in the local weather and adopting a number of steps to change agricultural practices. The results indicate the importance of understanding of community perception in designing policies and projects for effective adaptation strategies allowing local participation to cope with the impacts of climate change.

\section{Keywords}

Environment and Agriculture, Resource Conserving Agriculture, Climate Change Perception, Impacts of Climate Change, Farmers' Perception, Participatory Method, Ethiopia

\section{Introduction}

Efforts during last few decades had provided Africa with some success in increasing net agricultural productivi-

How to cite this paper: Belachew, O. and Zuberi, M.I. (2015) Perception of Climate Change and Livelihood of a Farming Community of Maruf Kebele, Central Oromia, Ethiopia. American Journal of Climate Change, 4, 269-281. 
ty [1], but rapid population growth and environmental degradation acted to diminish the outcome of this success in many countries like Ethiopia [2]. With continued increase in population pressure and land holdings continuously shrinking, many poor smallholders have resorted to more frequent cropping, curtailing traditional long fallows and increased use of inorganic fertilizers [3]-[6]. Ethiopia is one leading Sub-Saharan country to liberalize its economy and develop poverty reduction strategies through market-led, broad based agricultural development during early 2000s, so in the 2012/13 fiscal year Ethiopia's economy grew by $9.7 \%$, the tenth year in a row of robust growth. Agriculture, which accounted for $42.7 \%$ of GDP, grew by $7.1 \%$, while industry, accounting for $12.3 \%$ of GDP, rose by $18.5 \%$ and services, with $45 \%$ of GDP, increased by $9.9 \%$ in $2012 / 2013$. Although Africa's average growth declined from 5\% in 2010 to 3.4\% in 2011, the Ethiopian economy continued on the high-growth trajectory, and this momentum was expected to continue in 2012 and 2013 [7]. However, the growth in economy has been unevenly distributed, in most rural areas lasting effects of poverty, hunger, malnutrition still weigh heavily on the Ethiopian economy [8]. As 93\% of Ethiopians are currently engaged in small scale agriculture and other manual intensive activities, economic loss due to malnutrition estimated to cause reduced productive capacity at ETB 12.8 billion in 2009 (1 ETB = 0.5 US\$) which is equivalent to 3.8\% of GDP [9]. Ethiopia being the second most populous country in Africa (more than 82.9 million people), the rural population accounting for $82.4 \%$ [11], majority depending on traditional rainfed agriculture in the small farm dominated agriculture sector, the stability and sustainability of development have been heavily dependent on climate. Traditional agriculture, dominated by non-mechanized farming in highly uneven landscape, small-scale farmers is responsible for $95 \%$ of the cultivated land, mainly for subsistence needs [2] employing $80 \%$ of the population. Entire food supply comes from rain fed subsistent agriculture and rainfall failure means loss of major livelihood source, which affirms that improving agricultural production is of paramount importance for the country's economic progress [11]; especially in the background of wide poverty, food security has a primary focus not only in Ethiopia but all over Africa. In fact, different types of traditional small farm systems are providing food for more than 70\% of the global population [12]. Most of Ethiopian subsistence farmers have small land holdings, the average of 1.2 hectares of land, with $55.13 \%$ less than one hectare [2]. Thus, through strengthening these traditional small food production systems with a balance of modern knowledge/technology and environmental management using traditional knowledge with economic support, the countries like Ethiopia can try to attain sustainable food production [12].

Traditional agriculture here in Ethiopia, follows age old practices that evolve before introduction of high yielding varieties and synthetic agro-chemicals. Many small scale farmers are still adapting the local varieties, using local land-climate-vegetation characteristics for sustaining productivity and conserving the natural resource base. In modern terms this "resource-conserving agriculture" has proved to have sound potential for improving livelihoods of smallholders in Africa [13]-[16]. This is because, "resource-conserving agriculture" makes the best use of natural ecosystem's goods and services without compromising their future use promoting social, environmental and health goals along with productivity gains [17]. Examination of 31 documented cases of African and Latin American farmers adopting "resource conserving agriculture" found that yield improved in 19 of the 25 cases that reported on it, food security improved in seven of eight cases, and net income improved in 19 of 23 cases [18] and observed that successful "resource conserving agriculture" initiatives did not occur spontaneously rather required a variety of skills from smallholders and their allies which included adaptive farm management, effective producer organizations, entrepreneurship, capacity to innovate, value addition and boundary spanning, these being noted in the case of traditional farming in Ethiopia [19].

Unfortunately, the struggling Ethiopian small farmers and pastoralists have already been hit hard by climate variability, losing harvests and livestock to drought, floods and struggling to survive amid changing rainfall patterns [20]. Sub-Saharan Africa is considered one of the most vulnerable regions to climate change, because of the high exposure and the low adaptive capacity of agriculture which is the most important livelihood [21]. Mean annual temperature of Ethiopia has already increased by $1.3^{\circ} \mathrm{C}$ between 1960 and 2006, also daily temperature data indicate significantly increasing trends in the frequency of hot days, and much larger increasing trends in the frequency of hot nights [22]. Continued changing patterns and intensities of rainfall with increasing temperatures expected to have dire consequences for all Ethiopians, but especially more than 70 million poor rural people whose survival depended on rainfed agriculture (farming and/or pastoralism), in 2005, 39\% of Ethiopia's population lay below the national poverty line [23]. As the impacts of climate hazards and change occur alongside other trends, for example, population growth, land degradation, poor infrastructure, and low opportunities for markets, indicating the compounded nature of the problems faced by the rural community; the efforts to 
tackle climate hazards, variability and change in Ethiopia must be aligned with the overall development plans [24] [25]. Despite the Government of Ethiopia and other development actors giving widespread recognition of this by planning for climate change, most attempts are isolated and suffer from under-investment [2] [26] [27]. There is an important need of in depth research and closer scrutiny of how the local climate is changing, what the local communities are thinking about this change, what the small farmers can do in the long term as adaptations, and possible interventions/future investments needed to deliver sustainable results [22] [28] [29]. As indicated above, till now, the Ethiopian (also most African) agriculture has remained rather "traditional and ecological"-little change being experienced like "agricultural intensification" but to cater the need of the increased population, the traditional system has proved insufficient, has to be improved especially to cope with the climate change instabilities. For such a need the necessity for "ecological intensification" under unfavorable (mostly rain-fed) conditions was advocated which depends on reducing the reliance on subsistence cereal production and integration with livestock enterprises, greater crop diversification and agroforestry practices that may ensure higher economic value and soil conservation [30]. So, to understand the nexus of climate change and sustainable development, what needed is an in-depth field survey to find out the local community's ideas and perceptions and how they are responding to climate irregularities. As in most vulnerable communities, there is a symbiotic relation between lives, livelihoods and the biophysical environment. It is hypothesized that in response to the climate change the small farmers, in the way of the process of adaptation to all changes and survival strategy, may have modified and/or replaced many practices which have become unsustainable and adopt new ones can be demonstrated in the present study in the Highlands of Ethiopia. This understanding is also important for understanding the level of success of the process of constant adjustment to change be considered as an indicative of the adaptive capacity and knowledge of the rural farmers as has been stressed for attaining sustainable development [31].

\section{Materials and Methods}

The study area Maruf Kebele in Tokke Kutaye district of West Shewa zone, Central Oromia of Ethiopia, is located at latitudes $08^{\circ} 59^{\prime} 01.1 \mathrm{~N}$ and longitude $37^{\circ} 46^{\prime} 27.6 \mathrm{E}$ (Figure 1) situated in the upper part of the Guder watershed draining to the Abay (Blue Nile).

The altitude of the district ranges from 1600 to 3192 masl receiving a mean annual rainfall of 800 - $1000 \mathrm{~mm}$, with the mean annual temperature from $10^{\circ} \mathrm{C}$ to $29^{\circ} \mathrm{C}$ [32]. The Cholle, Ediris, Gura, Chancho, Dima, Arba and Kolba are small rivers/rivulets of the district, the soil being characterized by $48 \%$ red, $27 \%$ black and $25 \%$ red and black clay mixture. Land use data given by the Office indicated 998 hectare $(80 \%)$ is under production of different crops and 182 hectares (15\%) is occupied by grazing and bush lands while the remaining 68 hectares (5\%) was allocated for residential area and other uses. Data collected from the homesteads of the area showed the average annual income per homestead was Birr 12583.00 (=630.00 US\$); more than 50\% being poor had lower income that the average only having less or equal to half a hectare of land, field crops accounting for $41.00 \%$ of this income [19].

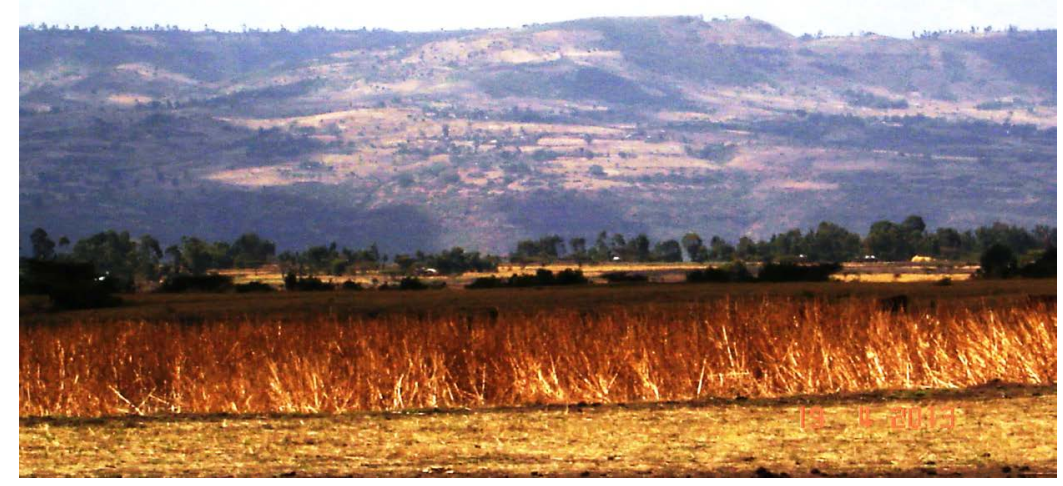

Figure 1. A general view of the landscape with harvested crop field, village with trees and the mountain range in the study area. 
To understand the perception of the local communities about climate change, a group of statements were prepared, Likert Scale (1 - 5) was used to understand community perception on climate change, its impacts and coping strategies. The levels of community perception was rated form "strongly agree" (5) to "strongly disagree" (1) on the scale from responses to the statements summarized and presented to indicate important characteristics of climate variability, its impacts on their livelihoods at local level and local coping strategies from the community's insight.

For examining the community's climate related understanding, experiences and its relation to their livelihoods, an approach similar to that used by "USAID_Participatory Assessment and Learning Tool”

(http://filestore.wikiadapt.org/wikiADAPT/Mentalmodels.pdf and

http://filestore.wikiadapt.org/wikiADAPT/HistoricalMatrix.pdf) for assessing how community members understand climate have been used. A focus group of elderly men (15) and women (10) who have been living for long (over 50 years) in the area were selected from the community to discuss about climate and farming (crops, animals and trees).The discussion was facilitated in local language (Oromiffa), as these community members lived for long periods in the area had good understanding of conditions and changes in their surrounding and also about the "normal climate conditions". Discussion was started by posing questions such as what are the "good" seasons and what were the "bad" seasons, how did they understand and describe climate and climate change at the local levels. The participants described "good season" as that give enough rain with regular distribution that can support crops, trees and animals in sufficient amount, there would be no fear of starvation and insecurity to the family; whereas they described "bad" season associated with low and irregular rains, heat, hails and storms bringing crop damage and the fear to face food shortage, starvation and insecurity to the family. The participants were solicited to identify and list the bad and good points of the earlier as well as during recent years in a chart and filter tip pen, the main memorable indicators of climate situation in the area from past were identified by the participants as rain fall, heat, hail and coolness. They also indicated what steps they already had taken or would take under the "problem” situations.

Socio-economic and agricultural survey were conducted during 2011-2012, over hundred (107) households were included (which were about $20 \%$ of the total households randomly chosen), the community typically include a large proportion (95\%) of small holder farmers with poorly equipped (Figure 2), land scare household with low education and economic status with (small land holding less 1 ha, having no or few domestic animals, less trees). Household socio-economic survey was conducted to estimate the contribution of different components to the income and the level of diversification both in the components of agriculture.

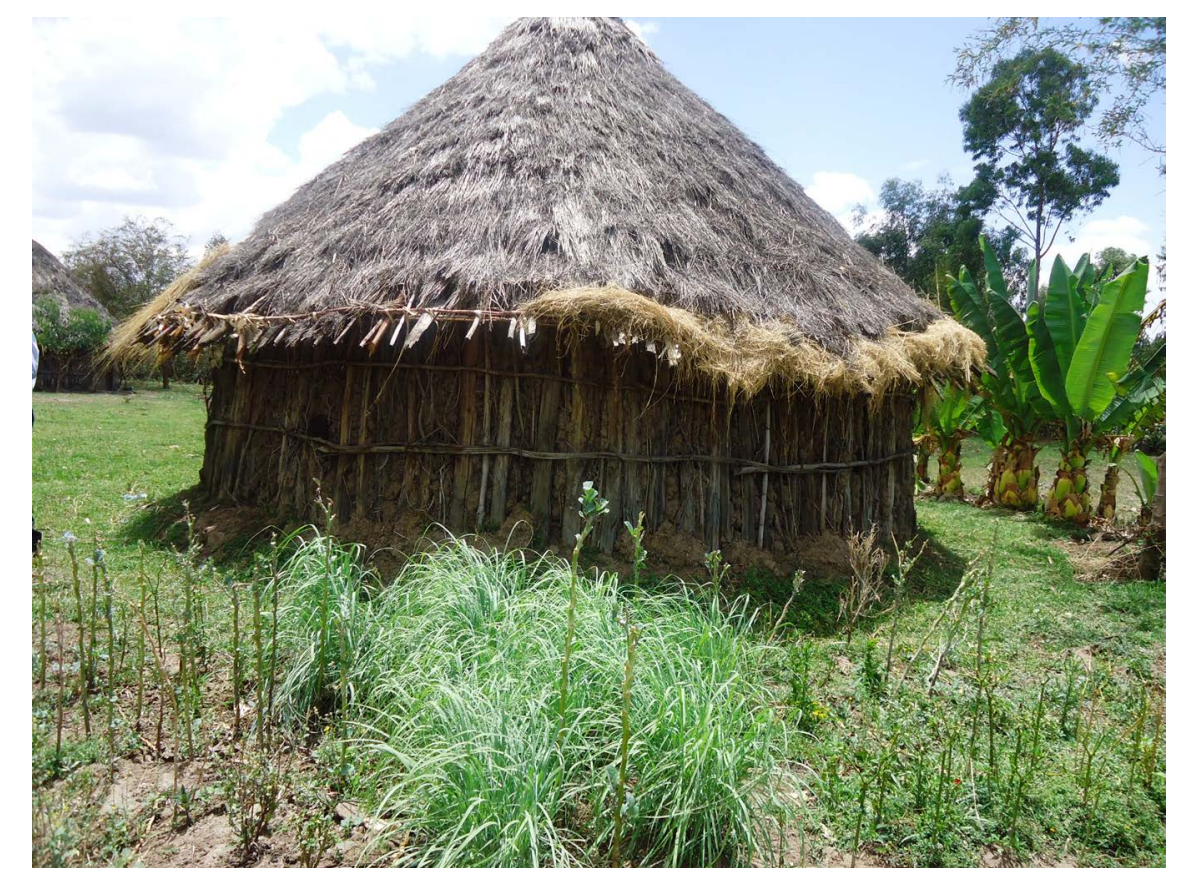

Figure 2. Home of a small farmer in the Highland of Ethiopia with enset and medicinal herbs. 


\section{Results and Discussion}

The climate change perception survey using five point Likert Scale (Table 1), has showed about two thirds $(66.36 \%)$ of the community "strongly agreed" to the questions regarding "heating of air in their locality increasing", "rain fall in their locality decreasing", "rain fall failed to properly support the full crop growth" and "springs, streams and wet areas dying out"; also another one fourth (around 25\%) "agreed" to the above statements. Regarding crop disease and pest infestation, again two thirds of the respondents had "strong agreement", while 24.3\% expressed "agreement". Nearly 59\% agree with the statement "prices of grain is hiking because of decreased productivity due to change of climate condition" with $27 \%$ in agreement. About $73 \%$ of the community strongly agreed that tree felling/deforestation is becoming more severe due to decrease of agricultural production because of climate change and $42 \%$ strongly agree to the statement that some community members are changing their place of residence due to poor agricultural production to support their families. Also, 56\% strongly agree to the statement that sources of livelihood of the community are changing due to changing climate conditions with $34.58 \%$ agreeing and $73.83 \%$ of the respondents strongly agree that irregularity of rain fall in the rainy season is increasing, with which $23.36 \%$ agreed. But only about $32 \%$ "strongly agreed" to the statement "community members have enough awareness about the climate change impacts" while 59\% simply agreed. For all the responses from Item 1 to 9 the most common response was the "Strongly Agree", the weighted mean above 4.3 for all except one (Table 2), showing the high level of awareness about climate change indicators and effects. Only for Item ten, regarding the climate change impacts only $31 \%$ "strongly agreed".

When the scientific aspect of climate change is considered, the trend for Africa shows warming of approximately $0.7^{\circ} \mathrm{C}$ over most of the Continent during the twentieth century; a decrease in rainfall over portions of the Sahel (South Sahara) while an increase in rainfall in East Central Africa [33]. Over the next century, warming trends are expected to continue over Africa, the large-scale picture one of drying in much of the Subtropics and an increase or small variation in precipitation in the Tropics, increasing the rainfall gradients, climate change

Table 1. A bipolar Likert scale measuring positive or negative response to statements on climate change $(\mathrm{N}=107)$ (the upper figures in the table are numbers of household heads and lower figures \%).

\begin{tabular}{|c|c|c|c|c|c|c|c|}
\hline \multirow[b]{2}{*}{ No } & \multirow[b]{2}{*}{ Statement point } & \multicolumn{6}{|c|}{ Scales of agreement ${ }^{*}$} \\
\hline & & St $=5$ & $A=4$ & $\mathbf{N}=\mathbf{3}$ & $\mathrm{SI}=2$ & $\mathbf{D}=1$ & $\begin{array}{l}\text { Weighted } \\
\text { mean }\end{array}$ \\
\hline 1 & $\begin{array}{l}\text { Temperature/heat is rising from time to } \\
\text { time when compared with similar season in the past. }\end{array}$ & $\begin{array}{c}71 \\
66.36 \%\end{array}$ & $\begin{array}{c}27 \\
25.23 \%\end{array}$ & $\begin{array}{c}5 \\
4.67 \%\end{array}$ & $\begin{array}{c}2 \\
1.87 \%\end{array}$ & $\begin{array}{c}2 \\
1.87 \%\end{array}$ & 4.52 \\
\hline 2 & $\begin{array}{l}\text { Rain fall amount decreasing, setting time } \\
\text { lagging behind rain stops earlier than in the past. }\end{array}$ & $\begin{array}{c}67 \\
62.62 \%\end{array}$ & $\begin{array}{c}29 \\
27.10 \%\end{array}$ & $\begin{array}{c}6 \\
5.61 \%\end{array}$ & $\begin{array}{c}2 \\
1.87 \%\end{array}$ & $\begin{array}{c}3 \\
2.80 \%\end{array}$ & 4.45 \\
\hline 3 & $\begin{array}{l}\text { Rain fall can't properly support full crop growth } \\
\text { period than earlier times, springs, } \\
\text { streams and pond dying out. }\end{array}$ & $\begin{array}{c}73 \\
68.22 \%\end{array}$ & $\begin{array}{c}25 \\
23.36 \%\end{array}$ & $\begin{array}{c}5 \\
4.67 \%\end{array}$ & $2.80 \%$ & $\begin{array}{c}1 \\
0.93 \%\end{array}$ & 4.48 \\
\hline 4 & $\begin{array}{l}\text { Crop disease/pest infestation increasing } \\
\text { more problem than earlier times. }\end{array}$ & $\begin{array}{c}72 \\
67.29 \%\end{array}$ & $\begin{array}{c}26 \\
24.30 \%\end{array}$ & $\begin{array}{c}2 \\
1.87 \%\end{array}$ & $\begin{array}{c}4 \\
3.74 \%\end{array}$ & $\begin{array}{c}3 \\
2.80 \%\end{array}$ & 4.50 \\
\hline 5 & $\begin{array}{l}\text { The prices of grain is hiking because of } \\
\text { decreased productivity for climate change. }\end{array}$ & $\begin{array}{c}63 \\
58.88 \%\end{array}$ & $\begin{array}{c}29 \\
27.10 \%\end{array}$ & $\begin{array}{c}2 \\
1.87 \%\end{array}$ & $\begin{array}{c}10 \\
9.35 \%\end{array}$ & $\begin{array}{c}3 \\
2.80 \%\end{array}$ & 4.26 \\
\hline 6 & $\begin{array}{l}\text { Tree cutting/deforestation becoming severe } \\
\text { than earlier times due to climate change } \\
\text { to compensate the income and livelihoods. }\end{array}$ & $\begin{array}{c}78 \\
72.90 \%\end{array}$ & $\begin{array}{c}20 \\
18.69 \%\end{array}$ & $2.80 \%$ & $3.74 \%$ & $\begin{array}{c}2 \\
1.87 \%\end{array}$ & 4.57 \\
\hline 7 & $\begin{array}{l}\text { Some members are changing their homes } \\
\text { (moving to cities) due to inability of their agricultural } \\
\text { production to support them due to climate change. }\end{array}$ & $\begin{array}{c}45 \\
42.06 \%\end{array}$ & $\begin{array}{c}12 \\
11.21 \%\end{array}$ & $\begin{array}{c}3 \\
2.80 \%\end{array}$ & $\begin{array}{c}20 \\
18.69 \%\end{array}$ & $\begin{array}{c}27 \\
25.23 \%\end{array}$ & 3.26 \\
\hline 8 & $\begin{array}{l}\text { Some sources of livelihoods of the community } \\
\text { are changing due to changing climate conditions. }\end{array}$ & $\begin{array}{c}60 \\
56.07 \%\end{array}$ & $\begin{array}{c}37 \\
34.58 \%\end{array}$ & $\begin{array}{c}4 \\
3.74 \%\end{array}$ & $\begin{array}{c}4 \\
3.74 \%\end{array}$ & $\begin{array}{c}2 \\
1.87 \%\end{array}$ & 4.39 \\
\hline 9 & Irregularity of rain fall in rainy season is increasing. & $\begin{array}{c}79 \\
73.83 \%\end{array}$ & $\begin{array}{c}25 \\
23.36 \%\end{array}$ & $\begin{array}{c}3 \\
2.80 \%\end{array}$ & 0 & 0 & 4.71 \\
\hline 10 & $\begin{array}{l}\text { Community members are enough aware } \\
\text { of the climate change impacts. }\end{array}$ & $\begin{array}{c}34 \\
31.78 \%\end{array}$ & $\begin{array}{c}63 \\
58.88 \%\end{array}$ & $\begin{array}{c}5 \\
4.67 \%\end{array}$ & $\begin{array}{c}1 \\
0.93 \%\end{array}$ & $\begin{array}{c}4 \\
3.74 \%\end{array}$ & 4.14 \\
\hline
\end{tabular}

*5 = strongly agree, 4 = slightly agree, 3 = neutral, 2 = slightly disagree, 1 = strongly disagree. 
Table 2. Summary of communities' indicators to environmental and climate changes as perceived by local members in group discussions.

\begin{tabular}{|c|c|}
\hline Past condition depicted from memory & Present situation described \\
\hline $\begin{array}{l}\text { Statement on heat/low rain } \\
\text { 1. Only dogs were panting. } \\
\text { 2. Big trees were used to shade men and animals from heavy rain. } \\
\text { 3. Below trees there were grasses. } \\
\text { 4. Woolen/cotton made cloths were used. } \\
\text { 5. Children were shivering from cold. }\end{array}$ & $\begin{array}{l}\text { 1. All animals are panting including man. } \\
\text { 2. Trees are used to get shade from the burning sun. } \\
\text { 3. Below trees there are dust. } \\
\text { 4. No need of warmth giving clothes. } \\
\text { 5. Children are sweating from heat. }\end{array}$ \\
\hline $\begin{array}{l}\text { Statements on water availability } \\
\text { 1. Common comment: Plenty. } \\
\text { 2. River waters were clean and colorless. } \\
\text { 3. Rain water was absorbed as if they were on spongy, } \\
\text { seeds retained, facilitate natural regeneration of trees. } \\
\text { 4. Rain starts slow and become heavy, sometimes takes away men } \\
\text { and animals when water courses are full at middle of August. }\end{array}$ & $\begin{array}{l}\text { 1. Common comment: Scarce. } \\
\text { 2. River waters are unclear [mixed with soil and full of worms] } \\
\text { 3. Rain water not absorbed, runoff, erodes soil, wash } \\
\text { and remove soil boring animals \& tree seeds } \\
\text { in the soil and abolish natural regeneration of tree. } \\
\text { 4. Rains delayed, come sudden and loss of soil high, } \\
\text { Intense rain rare, may happen at times. }\end{array}$ \\
\hline $\begin{array}{l}\text { Tree harvest/deforestation contributing to climate change } \\
\text { 1. Trees rarely cut, if cut used to regenerate and } \\
\text { recover quick, after two years. } \\
\text { 2. No saw/sawmill was in the area, tree cutting was tiresome and } \\
\text { non-ethical. } \\
\text { 3. Many trees, ripe fallen fruits/seeds and many seedlings. } \\
\text { 4. Naturally dried and fallen branches were collected } \\
\text { as firewood, animal dung were thrown to field. } \\
\text { 5. Harbor many wild animals and wild fruits were plenty. }\end{array}$ & $\begin{array}{l}\text { 1. If one cuts a tree, the next visitor cuts even up roots the stem } \\
\text { hence no/very few natural regeneration. } \\
\text { 2. Saws among the common home implements, saw-mills all } \\
\text { around, cutting trees good business/profession. } \\
\text { 3. Trees isolated and barren/no seedlings, any available tree } \\
\text { cut for firewood/timber taken to market, animal dung } \\
\text { commonly used to compensate shortage of woods. } \\
\text { 4. Very rare wild animals that compete with men. } \\
\text { 5. Fruits/seeds rarely found in the soil to naturally germinate, } \\
\text { where available easily germinate. }\end{array}$ \\
\hline $\begin{array}{l}\text { Statement about rainfall } \\
\text { 1. Rainfall start in March and stops in November. } \\
\text { 2. Distribution smooth and peak was July and August. } \\
\text { 3. Children were shivering of cold when heavy rains. } \\
\text { 4. }\end{array}$ & $\begin{array}{l}\text { 1. Rain fall starts in late April or June and stops in October. } \\
\text { 2. Distribution is unpredictable, peak is either July/August or } \\
\text { sometimes September. } \\
\text { 3. Children are sweating from heat in rain. } \\
\text { 4. No running spring, even in most water } \\
\text { heads/eyes dry quick after rain. }\end{array}$ \\
\hline
\end{tabular}

scenarios on future warming across the continent ranging from $0.2^{\circ} \mathrm{C}$ per decade (mitigation scenario) to more than $0.5^{\circ} \mathrm{C}$ per decade (business as usual scenario) [34]-[36]. The north and south of the equatorial region, climate is dominated by the African Monsoon System [37], the Subtropical West Africa experiences one rainy season (May to September), modulated to a great extent by El Niño-Southern Oscillation (ENSO), sea surface temperatures (SSTs) over the Atlantic, and strong land-atmosphere interactions [38] [39]. In comparison, the Subtropical East Africa experiences two rainy seasons, the "long rains" (March to May) and the highly variable "short rains" (September to December), driven by the seasonal migration of the ITCZ 40] [41], Ethiopia included. Also, in all Ethiopian climate change models, climate analyses predict continuing temperature increases, their extent depending on emissions scenarios but by 2060, temperatures could increase by between $1.1^{\circ} \mathrm{C}$ and $3.1^{\circ} \mathrm{C}$, while predictions are more uncertain, rainfall patterns are also likely to change [28]. At the country and regional levels, there is no doubt about the really of climate change and its dire consequences, in fact many agencies involved are concerned and being active for mitigation and adaptation [21] [28] [42].

Regarding the community's perception about climate change through participatory approach, (Table 2), the statements of the community members expressed were, "in recent years the rains come later and finish earlier", "longer dry seasons with patchy distribution of rainfall", also statements like "more rivulets and springs have dried", "crop pests and animal diseases increased", "need plowing of unsuitable land", "soil erosion increased" all have been connected with recent climate change. When the participants discussed possible remedial steps they used in the past or planning to use now to reduce the negative impacts, they reported changes in the local livelihoods as listed below:

1) Repaired, improved and increased construction of bund/check dams to retain water on their fields; mostly done at the individual field levels with limited benefit (Figure 6),

2) Improved drainage systems, canals renovated and/or built around farm land to allow water out during heavy rains reducing soil loss,

3) Ensured increased use of river and spring water; canals and pits for transferring and storing rain water, also 
increasing infiltration;

4) Intensified efforts, at individual field level, to enforce gulley-control measures, leveled land more carefully and reduced plough/tillage;

5) Adoption of efforts growing more trees and shrubs, mentioned eucalyptus several times;

6) Expanding homestead based horticulture as cash crops, introducing chilli, green vegetables, sugarcane and herbal spices for marketing (Figures 3-6).

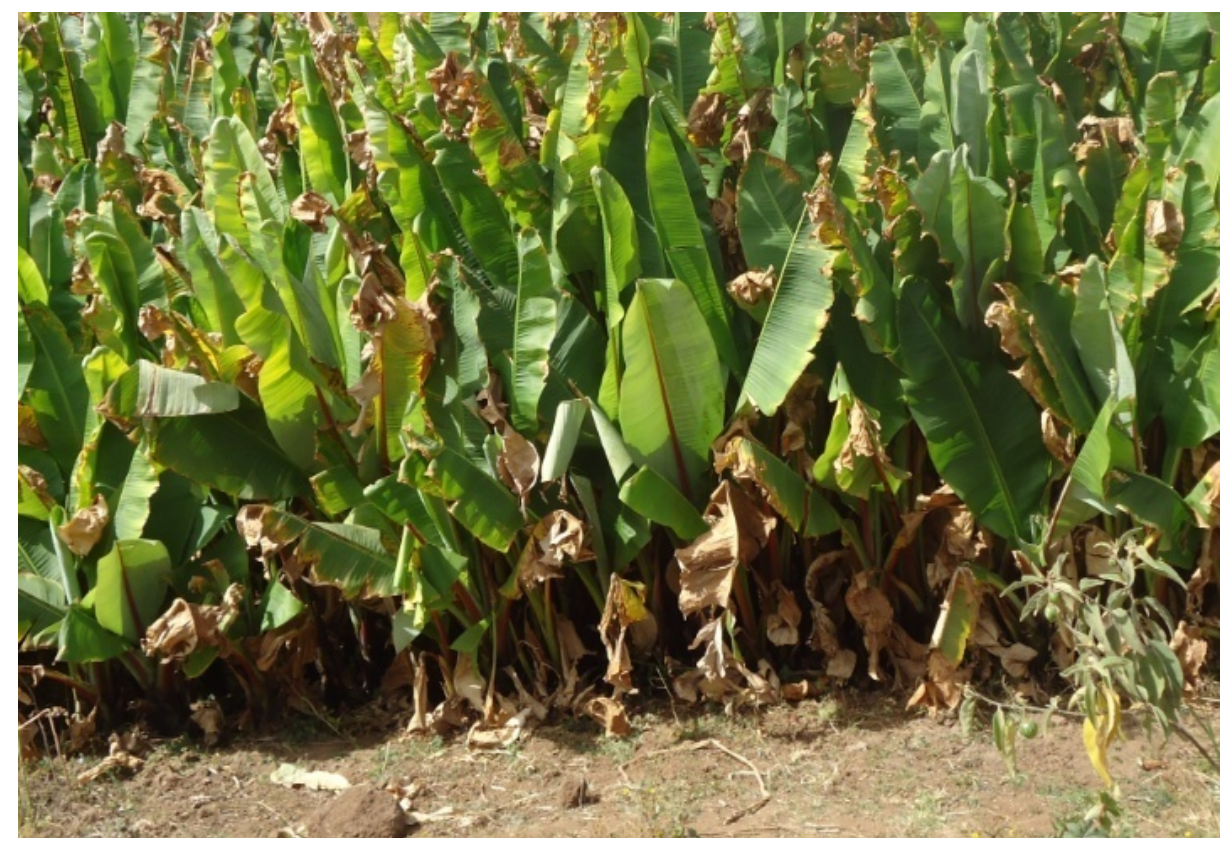

Figure 3. Enset in small farmer's field in the Highlands of Ethiopia.

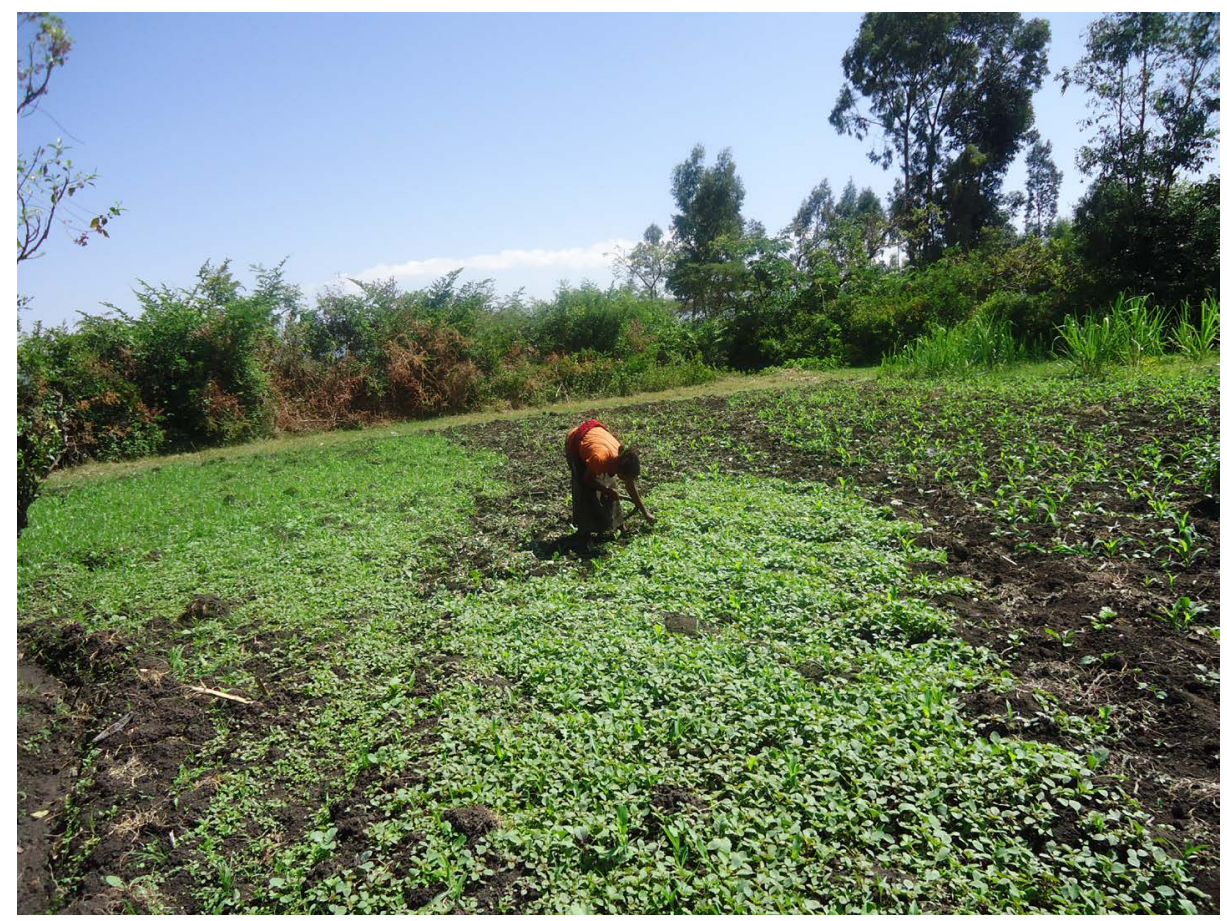

Figure 4. Home garden of a small farmer in the Highlands of Ethiopia with sugarcane, maize infested with weeds (amaranths and grasses). 


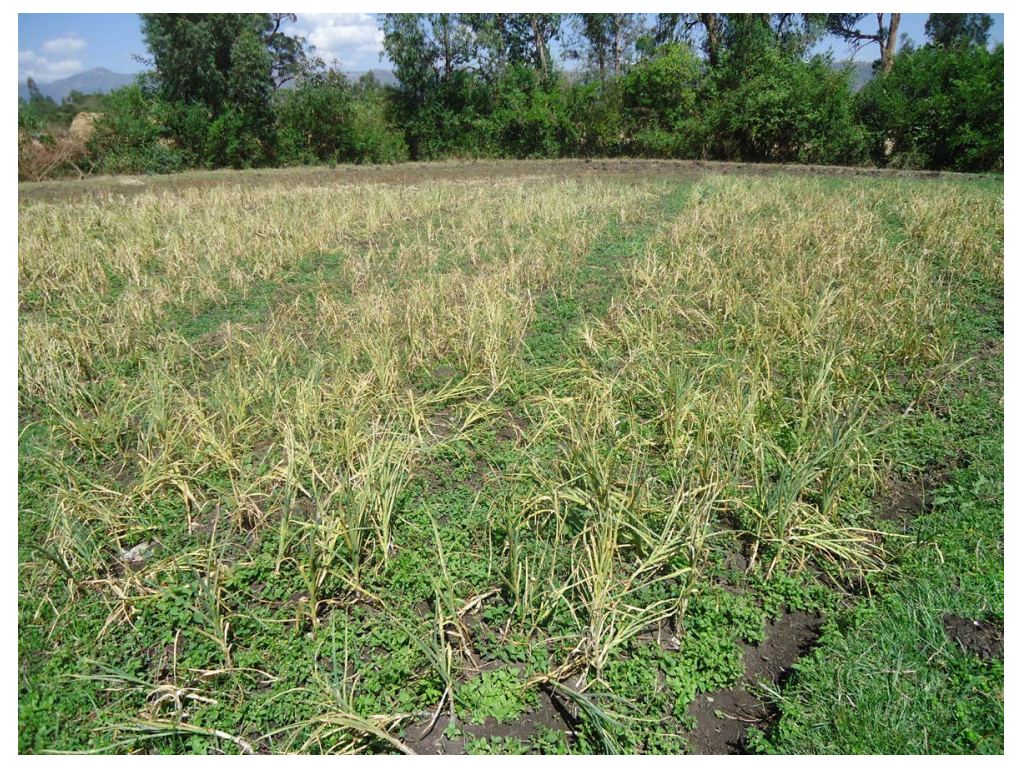

Figure 5. A crop field behind farmer’s home (garlic growing with weeds).

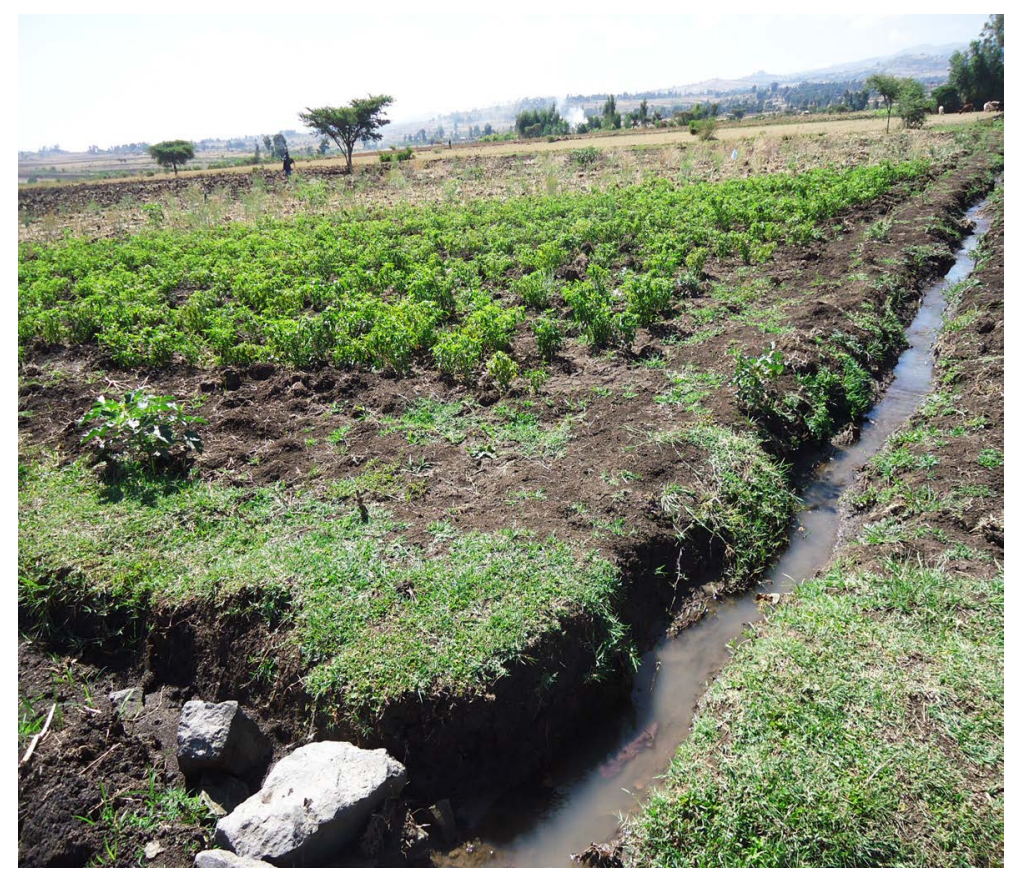

Figure 6. Crop field (green chilli) in the Highlands of Ethiopia with irrigation from nearby stream.

Many of the action mentioned to improve water use efficiency, water scarcity being one of the reasons for the pronounced vulnerability of the Ethiopian agricultural production system, there being extremely low level of water resources management, either in the form of poor watershed management or investment in water infrastructure [10]. This is more true in the Highlands of Ethiopia, the site of this study, home to the majority of Ethiopians dominated by small farm traditional agriculture. The impacts of change of rain fall regimes were given more importance by the community in group discussions; they think this has been directly affecting local vegetation especially tree growth and reproduction as reflected in reporting impacts like "tree cover with no 'spongy' soil underneath", "seeds rarely found in the soil to naturally germinate", "rain water runoff, erodes soil, remove tree seeds" "fewer seedlings in and around forest" and "no natural regeneration of trees". Field observa- 
tion and discussions indicated that in the past there was wide natural regeneration in and around forests and also people used to collect seedlings from the forests/forest edges for planting in their homes and crop fields, a practice no longer possible they reported because of scarcity of seedlings. Thus, both in nature and in homestead agroforestry tree propagation/regeneration likely to be affected by the climate change impacts, a number of studies also mentioned [43] [44].

It was evident that at the local level, the poor and impoverished rural community operate in the isolated, distant villages (Figure 1 and Figure 2) with no direct road connection from the village to the Highway (to the nearest towns of Guder or Ambo or the capital city Addis Ababa) and the villagers have to walk long distances to market their products. Yet, the two approaches adopted in the study-formal questionnaire survey (Likert type) and informal group discussion-both demonstrated the villagers' high level of awareness about climate change, its impacts and necessity for adaptation. Another recent report [22] also identified about $71 \%$ of the rural respondents in Ethiopia agreeing that there have been changes in the climate over the 20 - 30 years, in the amount of rainfall during the main season, delay in the timing, a reduction in the volume of rainfall insufficient for cropping.

Livelihood, on the whole, depending on agriculture in the study area which is characterized by mixed farming, cereal production, vegetable/horticulture farming, livestock keeping and trees/shrubs growing being the main components (Table 3), climate impacts are seen as a major factor by the farmers. Both field and homestead cropping being common, barley, wheat and teff were the main food crops in the past, but now niger (brassica) seed, linseed, chickpea and field beans and vegetables are also introduced, all these were used both for food and cash earnings (Table 3). All these field and home gardens (around four hundred ha) are rain-fed, traditional irrigation is practiced in very limited area about one fourth of the fields only for limited period of the year when water is available. Home garden crops such as enset or false banana (Figure 3), potato, carrot, beet root,

Table 3. Components of the farm agricultural system in the study area.

\begin{tabular}{|c|c|c|c|c|c|}
\hline Crops & Livestock type & Agro forestry trees & "Spice herbs & Off farm job & Horticultural crops \\
\hline Barley & Poultry & Buddleja polytachya & Kosorot & Crop trade & Enset (false banana) \\
\hline Wheat & Cows & Carisa edulis & Masarat, & Local drinks sale & Catha edulis \\
\hline Teff & Oxen & Albizia gummifera & Tenaddam, & Traditional articles craft & Coffee \\
\hline Linseed & Goat & Myrica salcifolia & Basobila & Traditional leather works & Citrus aurantifolia \\
\hline Field beans & Sheep & Celtis africana & Wild cabbage & Home shops & Rhamnus prinoides \\
\hline Niger (noug) & Donkeys & Cordia african & Costa (leafy vegetable) & Weaving & Guava \\
\hline Faba bean & Horses & Croton macrostachyas & Ethiopian potato & Farm implements & \\
\hline Cabbage & & Cuperssus lustanica & & Fermented drinks & \\
\hline Potato & & Dovyalis abyssinica & & Farm laborer & \\
\hline Tomato & & Ekebergia capensis & & Urban migration & \\
\hline Onion & & Eucalyptuslptus spp. & & & \\
\hline Garlic & & Ficus capensis & & & \\
\hline Beetroot & & Juniperus procera & & & \\
\hline Sugarcane & & Podocarpus falcatus & & & \\
\hline Carrot & & Premnas chimperi & & & \\
\hline $\begin{array}{l}\text { Abbasuyya } \\
\text { (chilli) }\end{array}$ & & Justricia schimperiana & & & \\
\hline Chickpea & & Prunus persica & & & \\
\hline Sweet potato & & Acacia abyssinica & & & \\
\hline
\end{tabular}

*Local names in Amharic (scientific identification to be done). 
cabbage, garlic (Figure 5), shallot, onion, sweet potato and sugar cane (for chewing) are managed by the women, now have a high contribution to the household income (Table 3). Another important source is domestic animals having a crucial role in the livelihoods of the community providing power for traction and transportation, food, fertilization (dung) and cash earning from both the products or live animal sale, though the poor farm households having few and only less valuable sheep and poultry. Also, woody trees and shrubs were reported as important sources of community livelihoods, getting economic (firewood, construction materials, farm implements, cash) and ecological benefits (shade, erosion control, wind break and food for animals). Common trees being Eucalyptus spp., Justricia schimperiana, Myrica salcifolia, Premna schimperi, Cuperssus lustanica Cuperssus lustanica, Carisa edulis, Juniperus procera, Maesa lanceolat, Dovyalis abyssinica and Celtis Africana. The small farmers were found to intensify homestead and agroforestry systems to cope with the negative impacts of climate change at the village levels.

As indicated in (Table 3), petty trade (both women and men), preparations and sales of local alcoholic drinks (women) has been indicated to generated additional income to the community members under economic stress. Handicraft activities such as weaving (men), pottery (women) and local leather works, traditional articles made by women from selected grass species also contribute to homestead income (Table 4). All these are being increasingly adopted as cropping has become difficult during recent years.

The farmers here have adopted different strategies to cope up with the consequences of climate change, the diverse components in their current farming system indicated this. They diversifying crops, barley, wheat and teff being the main cops, while maize and sorghum in patches and in home gardens; enset (false banana) and other shrubs, pulses (faba bean, lentil and chickpea), oil crops (linseed, noug) are now taking more areas in the cropping combinations. Tuber crops (potato, carrot, sweet potato, Ethiopian potato and beet) while cabbage, wild brassica/cabbage (as green vegetables), garlic, shallot, onion are among the important home garden grown horticultural crops along with sugarcane (for chewing), green chilli (Figure 6) and capsicum. Only during recent years, many women folks also adopting growing wild/semi wild herbal spices in their home gardens (Table 3 and Figure 2) for marketing [45]. Other important component in the traditional system gaining importance during recent years was identified as home/agro-forestry-very wide range of plant types for diverse uses getting prominence like guava and mango (Figure 7) for marketing and home consumption; also an array of domestic animals are increasing especially chicken with higher market prices of eggs and live birds.

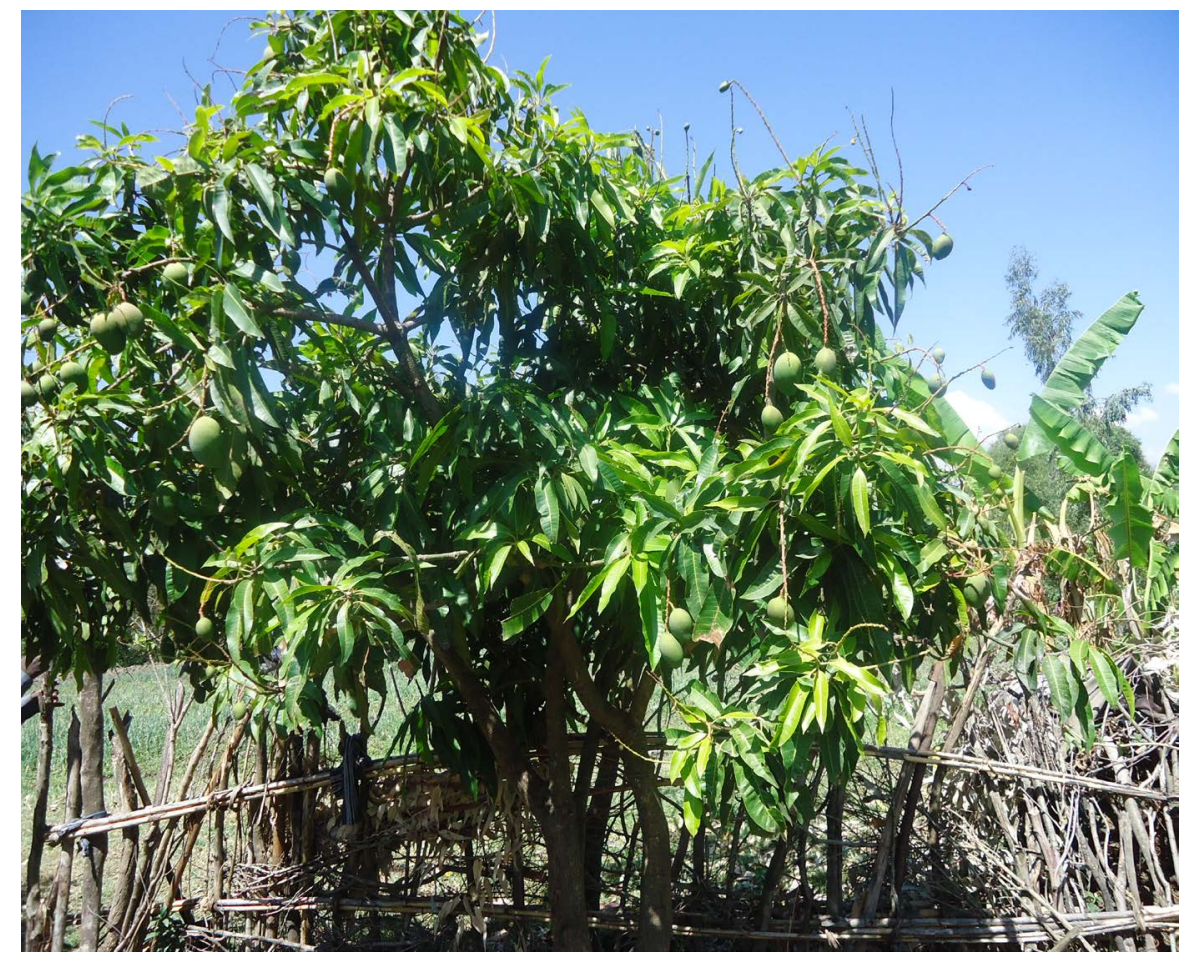

Figure 7. Home garden (mango tree) in the Highlands of Ethiopia. 
Table 4. Summary of average overall annual income (in Birr, 1 Birr = 0.5 US\$) from different sources.

\begin{tabular}{ccccccc}
\hline Statistic & Crops & Animals & Trees & Horticultural/vegetables & Off farm activities & Enset \\
\hline Mean & 12583.84 & 4626.21 & 3706.19 & 2283.70 & 3219.14 & 4579.45 \\
Median & 10185.00 & 4287.00 & 3361.00 & 1666.00 & 2506.00 & 4226.00 \\
Std. deviation & 8717.59 & 2127.71 & 2027.96 & 1674.70 & 1944.51 & 2165.93 \\
Skewness & 2.03 & 0.45 & 1.20 & 1.60 & 0.88 & 0.49 \\
Range & 46,399 & 9443 & 10,097 & 9237 & 7889 & 9615 \\
Minimum & 1209 & 505 & 614 & 282 & 451 & 772 \\
Maximum & 47,608 & 9948 & 10,711 & 9519 & 8340 & 10,387 \\
\hline
\end{tabular}

In the study area, though farming is the primary occupation for $81 \%$ of the sample household heads, a significant proportion has to combine some types of non-farming income sources into their livelihoods like a range of off-farm income earning activities, including paid employment, day laborer, petty trade; or move away to seek a livelihood elsewhere (Table 3). The high degree of dependence on farming activities calls for major adaptation to happen in the farming sector as this sector is directly affected by climate change [20]. This however, is not a good strategy, as agricultural investments are proved to reduce poverty more than investments in any other sector; in developing/developed countries, agricultural research provides returns of 20 to 80 per cent-a great investment in any economy [46] [47].

In order to understand the impact of climate change at the local level, it is important to recognize the interactions between climate change and wider development pressures, because people mostly adapt to the impact of climate change simultaneously with other wider development related issues, such as rising food prices, hunger/ malnutrition, the spread of disease/illness and competition over natural resources. It is also true that the impacts of climate change are not likely to be the same for all, the vulnerability to the impacts of climate change often comes from vulnerability in a general sense, like from poverty and marginalization. So, it makes little practical sense to talk about how people adapt to climate change in isolation, since adaptation is driven by a range of different pressures acting together. Supporting local adaptive capacity cannot, therefore, be seen in isolation as “climate change programming'. It is an intrinsic part of all development interventions. Widespread poverty through the mountain communities of the Highlands continues to be a major factor in food insecurity which is already a fact of life here, where the harsh climate, rough terrain, isolated villages, poor soils, high soil erosion and short fluctuating growing seasons often lead to low agricultural productivity, lost harvest and food deficits. Thus, climate change and extreme weather events like droughts, cloud bursts and flush floods are very likely to impact food security in the Highland regions particularly hard. Here, community participation and mainstreaming climate adaptation issue into other programs are highly desirable. The livelihood activities that were already adopted, supported and significantly contributed to climate change adaptation should be identified and incorporated in strategies by the government and other agencies.

In 2012, U.N. Secretary-General Ban Ki-moon assembled a team for suggestions regarding ending world poverty (the High Level Panel of eminent persons, HLP), recommended to "build resilience and reduce deaths from natural disasters” as the intensity of natural disasters is expected to increase with climate change. For example, Potato, a poor farmers crop in many developing countries of Africa, Asia and Latin America, has likely to have more diseases and less production under climate-change induced stress, as suggested the Consultative Group on International Agricultural Research (CGIAR) report in 2012. Even at high altitudes like the study site, late blight can have a devastating impact due to increased temperatures. Also likely to be affected, another homestead horticultural crop of the small farmers in Ethiopia, the production of coffee affected by soil erosion and rainfall changes, rising temperatures will increase the plant's vulnerability to pests and fungal diseases as predicted by the Centre for Agricultural Bioscience International (CABI) researchers.

\section{Conclusion}

All these indicate that the poor farmers need more information and easy technologies which should be adopted to fit the socio-economic and ecological reality of small holder systems in the tropics and hence these are to be developed locally. Adaptation actions in response to climate change are rarely new and innovative, what is important is whether the community are aware of the change, what they are thinking and planning, i.e. thinking 
about climate and trying to change their livelihood strategies and action for better future.

\section{References}

[1] Pretty, J., Toullmin, C. and Williams, S., (2011) Sustainable Intensification in African Agriculture. International Journal of Agricultural Sustainability, 9, 5-24. http://dx.doi.org/10.3763/ijas.2010.0583

[2] MoFED (2007) Ministry of Finance and Economic Development. PASDEP Annual Progress Report 2006/07, Building on Progress: A Plan for Accelerated and Sustained Development to End Poverty (PASDEP 2005/06-2009/10). Addis Ababa.

[3] McCann, J.C. (1995) People of the Plow: An Agricultural History of Ethiopia, 1800-1990. University of Wisconsin Press, Madison.

[4] Henao, J. and Baanante, C. (2006) Agricultural Production and Soil Nutrient Mining in Africa: Implications for Resource Conservation and Policy Development [Online]. 13 p. http://www.eurekalert.org/africasoil/report/Soil_Nutrient_Mining_in_Africa_Report_Final.pdf

[5] Cobo, J., Dercon, G. and Cadisch, G. (2010) Nutrient Balances in African Land Use Systems across Different Spatial Scales: A Review of Approaches, Challenges and Progress. Agriculture, Ecosystems and Environment, 136, 1-15. http://dx.doi.org/10.1016/j.agee.2009.11.006

[6] Moebius-Clune, B.N., et al. (2011) Long-Term Soil Quality Degradation along a Cultivation Chronosequence in Western Kenya. Agriculture, Ecosystems and Environment, 141, 86-99. http://dx.doi.org/10.1016/j.agee.2011.02.018

[7] African Economic Outlook (2014) http://www.africaneconomicoutlook.org/en/countries/east-africa/ethiopia/

[8] WFP (World Food Program) (2014) Hunger Ethiopia. https://www.wfp.org/stories/

[9] ECA \& WFP (2014) http://www.costofhungerafrica.com/high-level-panel-discussion-in-abuja/

[10] World Bank (2006) Ethiopia: Managing Water Resources to Maximize Sustainable Growth. A World Bank Water Resources Assistance Strategy for Ethiopia. Washington DC, World Bank.

[11] World Bank (2011) The World Bank, World Development Indicators.

[12] World Economic and Social Survey (2011) Department of Economic and Social Affairs of the United Nations Secretariat. http://www.un.org/en/development/desa/policy/wess/wess_current/2011wess.pdf

[13] Crucefix, D. (1998) Organic Agriculture and Sustainable Rural Livelihoods in Developing Countries. Soil Association, Bristol.

[14] Sanchez, P.A. (2002) Soil Fertility and Hunger in Africa. Science, 295, 2019-2020. http://dx.doi.org/10.1126/science.1065256

[15] Parrott, N. and van Elzakker, B. (2003) Organic and Like-Minded Movements in Africa: Development Andstatus. International Federation of Organic Agriculture Movements (IFOAM), Bonn.

[16] Hine, R. and Pretty, J. (2006) Promoting Production and Trading Opportunities for Organic Agricultural Products in East Africa. United Nations Environment Programme (UNEP) - United Nations Conference on Trade and Development (UNCTAD) Capacity Building Task Force on Trade Environment and Development, New York and Geneva.

[17] Giovannucci, D., Scherr, S., Nierenberg, D., et al. (2012) Food and Agriculture: The Future of Sustainability. A Strategic Input to the Sustainable Development in the 21st Century (SD21) Project. United Nations Division for Sustainable Development, New York. http://www.un.org/esa/dsd/dsd_sd21st/21_pdf/agriculture_and_food_the_future_of_sustainability_web.pdf

[18] Bennett, M. and Franzel, S. (2013) Can Organic and Resource-Conserving Agriculture Improve Livelihoods? A Synthesis. International Journal of Agricultural Sustainability, 11, 193-215. http://dx.doi.org/10.1080/14735903.2012.724925

[19] Olika, B. (2013) Contributions of Traditional Agroforestry System to Local Livelihood and to Climate Change Impacts Mitigation: Perception of Farming Community; Maruf Kebele; Central Oromia. M.Sc. Thesis (Unpublished), Ambo University, Ambo.

[20] Tazeze, A., Haji, J. and Ketema, M. (2012) Climate Change Adaptation Strategies of Smallholder Farmers: The Case of Babilie District, East Harerghe Zone of Oromia Regional State of Ethiopia. Journal of Economic and Sustainable Development, 1, 1-12.

[21] IPCC (2007) Working Group II—Chapter 9: Africa.

[22] ACCCA (2010) Advancing Capacity to Support Climate Change Adoptation, Project No. 093. Improving DecisionMaking Capacity of Small Holder Farmers in Response to Climate Risk Adaptation in Three Drought-Prone Districts of Tigray, Northern Ethiopia Farm—Level Climate Change Perception and Adaptation in Drought Prone Areas of Tigray, Northern Ethiopia. 
[23] UNDP (2011) The 2011 Human Development Report. United Nations Development Programme, New York.

[24] Pettengell, C. (2010) Climate Change Adaptation: Enabling People Living in Poverty to Adapt. Oxfam GB, Oxford.

[25] Ludi, E., Getnet, M., Wilson, K., Tesfaye, K., Shimelis, B., Levine, S. and Jones, L. (2011) Preparing for the Future? Understanding the Influence of Development Interventions on Adaptive Capacity at Local Level in Ethiopia. Africa Climate Change Resilience Alliance (ACCRA).

[26] CSA (Central Statistical Agency) (2008/09) Statistical Report on Area and Production of Crops. Addis Ababa.

[27] Bekele, T. (2010) Smallholders’ Involvement in Commercial Agriculture/Horticulture. AAACP-Funded Series of High Value Agriculture Seminars, EHPEA.

[28] ACCRA (2010) The Africa Climate Change Resilience Alliance. http://community.eldis.org/accra/

[29] Flora, C.B. (2010) Food Security in the Context of Energy Resource Depletion: Sustainable Agriculture in Developing Countries. Renewable Agriculture and Food Systems, 25, 118-128. http://dx.doi.org/10.1017/S1742170510000177

[30] Cassman, K.J. (1999) Ecological Intensification of Cereal Production System: Yield Potential, Soil Quality and Precision Agriculture. Proceedings of the National Academy of Sciences of the United States of America, 96, 5952-5959. http://dx.doi.org/10.1073/pnas.96.11.5952

[31] Griggs, D., Stafford-Smith, M., Gaffney, O., Rockström, J., Öhman, M.C., Shyamsundar, P., Steffen, W., Glaser, G., Kanie, N. and Noble, I. (2013) Sustainable Development Goals for People and Planet Griggs. Nature, 495, 305-307. http://dx.doi.org/10.1038/495305a

[32] Kutaye, T. (2012) District Agriculture Office (Unpublished). Oromia, Ethiopia.

[33] Desanker, P.V. (2009) Impact of Climate Change on Life in Africa. WWF Climate Change Program, Washington DC.

[34] Hulme, D., Doherty, R.M., Ngara, T., New, M.G. and Lister, D. (2001) African Climate Change: 1900-2100. InterReserach Climate Research, 17, 145-168. http://dx.doi.org/10.3354/cr017145

[35] McSweeney, C., New, M. and Lixcano, G. (2007) Ethiopia-UNDP Climate Change Country Profiles, UNDP-Ethiopia.

[36] McSweeney, C., New, M. and Lizanco, G. (2008) UNDP Climate Change Country Profiles: Uganda/Ethiopia/Mozambique. UNDP, Oxford.

[37] Polcher, J., Parker, D.J., Gaye, A., et al. (2011) AMMA’s Contribution to the Evolution of Prediction and DecisionMaking Systems for West Africa. Atmospheric Science Letters, 12, 2-6. http://dx.doi.org/10.1002/asl.320

[38] Cook, K.H. (2008) Climate Science: The Mysteries of Sahel Droughts. Nature Geoscience, 1, 647-648. http://dx.doi.org/10.1038/ngeo320

[39] Cook, K.H. and Vizy, E.K. (2006) Coupled Model Simulations of the West African Monsoon System: Twentieth- and Twenty-First-Century Simulations. Journal of Climate, 19, 3681-3703. http://dx.doi.org/10.1175/JCLI3814.1

[40] Black, E., Slingo, J. and Sperber, K.R. (2003) An Observational Study of the Relationship between Excessively Strong Short Rains in Coastal East Africa and Indian Ocean SST. Monthly Weather Review, 131, 74-94. http://dx.doi.org/10.1175/1520-0493(2003)131<0074:AOSOTR>2.0.CO;2

[41] Shongwe, M.E., van Oldenborgh, G.J., van den Hurk, B. and van Aalst, M. (2011) Projected Changes in Mean and Extreme Precipitation in Africa under Global Warming. II. East Africa. Journal of Climate, 24, 3718-3733. http://dx.doi.org/10.1175/2010JCLI2883.1

[42] CEEPA (2006) Climate Change and African Agriculture Policy Note No. 10. Centre for Environmental Economics and Policy in Africa (CEEPA), University of Pretoria, Pretoria.

[43] Azene Bekele, T., Birnie, A. and Tengbnäa, B. (1993) Useful Trees and Shrubs for Ethiopia. Identification, Propagation and Management for Agricultural and Pastoral Communities. Regional Soil Conservation Unit (RSCU), Swedish International Development Authority, Nairobi, Kenya.

[44] Teketay, D. (1996) Seed Ecology and Regeneration in Dry Afromontane Forests of Ethiopia. Ph.D. Thesis, Swedish University of Agricultural Sciences, Umeå.

[45] Zuberi, M.I., Kebede, B., Gosaye, T. and Belachew, O. (2014) Species of Herbal Spices Grown in the Poor Farmers' Home Gardens of West Shoa, Highlands of Ethiopia: An Ethnobotanical Account. Journal of Biodiversity and Environmental Sciences (JBES), 4, 164-185.

[46] Alston, J. (2010) The Benefits from Agricultural Research and Development, Innovation and Productivity Growth. OECD Food, Agriculture and Fisheries Papers, No. 31, OECD Publishing. http://dx.doi.org/10.1787/5km91nfsnkwg-en

[47] Roling, N. (2010) The Impact of Agricultural Research: Evidence from West Africa. Development in Practice, 20, 959-971. http://dx.doi.org/10.1080/09614524.2010.513724 